\title{
HIV-related stigma and discrimination: a study of health care workers in Banda Aceh, Indonesia
}

\author{
Harapan Harapan, ${ }^{1,2}$ Syarifah Feramuhawan, ${ }^{1,2}$ Hendra Kurniawan, ${ }^{2,3}$ Samsul Anwar, ${ }^{4}$ Mohd. Andalas, ${ }^{5}$ \\ Mohammad B. Hossain ${ }^{6}$ \\ ${ }^{1}$ Medical Research Unit, Faculty of Medicine, Syiah Kuala University, Banda Aceh, Indonesia \\ ${ }^{2}$ Department of Public Health, Faculty of Medicine, Syiah Kuala University, Banda Aceh, Indonesia \\ ${ }^{3}$ Epidemiology Unit, Faculty of Medicine, Prince of Songkhla University, Songkhla, Thailand \\ ${ }^{4}$ Department of Applied Mathematics, National Dong Hwa University, Taiwan, Republic of China \\ ${ }^{5}$ Department of Obstetrics and Gynecology, Faculty of Medicine, Syiah Kuala University, Banda Aceh, Indonesia \\ ${ }^{6}$ Department of Social \& Environmental Health Research, London School of Hygiene \& Tropical Medicine, London, United Kingdom
}

\begin{abstract}
Abstrak
Latar belakang: Tujuan dari penelitian ini untuk mengetahui tingkat stigma dan diskriminasi tenaga kesehatan terhadap orang dengan HIVIAIDS (ODHA) serta menentukan faktor yang mempengaruhinya.

Metode: Penelitian ini dilakukan di Rumah Sakit Umum Dr. Zainoel Abidin Banda Aceh, Indonesia dengan menggunakan metode potong lintang. Delapan puluh sembilan tenaga kesehatan diikutsertakan dalam penelitian yang dipilih secara purposif. Analisis korelasi, analisis varian (Anova) dan analisis t-test digunakan sesuai dengan jenis data. Model analisis linier berganda digunakan untuk menentukan faktor prediktor munculnya stigma dan diskriminasi pada tenaga kesehatan.

Hasil: Didapatkan bahwa stigma dan diskriminasi masih tinggi pada tenaga kesehatan. Analisis bivariat didapatkan bahwa jenis tenaga kesehatan, pendidikan, status perkawinan, pengetahuan tentang penularan dan pencegahan HIV dan ketakutan irasional terhadap penularan HIV berpengaruh secara bermakna terhadap tingkat stigma $(p<0,05)$. Jenis tenaga kesehatan, status perkawinan, umur, pengetahuan tentang penularan dan pencegahan HIV dan ketakutan irasional terhadap penularan HIV berpengaruh secara bermakna terhadap tingkat disriminasi $(p<0,05)$. Model regresi linier berganda mendapatkan bahwa jenis tenaga kesehatan, dan ketakutan irasional terhadap penularan HIV berhubungan dengan stigma $\left(R^{2}=0,230\right)$, sedangkan pengetahuan tentang penularan dan pencegahan HIV berhubungan dengan disriminasi $\left(R^{2}=0,119\right)$.
\end{abstract}

Kesimpulan: Ketakutan irasional terhadap penularan HIV dan jenis tenaga kesehatan merupakan faktor prediktor munculnya stigma sedangkan pengetahuan tentang penularan dan pencegahan HIV merupakan faktor prediktor munculnya diskriminasi pada tenaga kesehatan terhadap ODHA. (Med J Indones. 2013;22:22-9)

\begin{abstract}
Background: The aim of this study was to identify the level of stigmatized and discriminatory attitudes towards people living with HIV (PLHIV) among health care workers (HCWs) and the factors that influenced these attitudes.

Methods: This research was conducted at Dr. Zainoel Abidin General Hospital Banda Aceh, Indonesia. A cross-sectional study design was adopted for this research. Eighty nine HCWs were included in this study and they were selected purposively. Correlation analysis, analysis of variance and independent sample $t$ test analysis was used according to the type of data. Finally, a multiple linear regression model was used to identify the predictor factor for stigmatized and discriminatory attitudes.

Results: We found that the level of stigmatized and discriminatory attitudes was high. Bivariate analysis showed that type of HCW, education, marital status, knowledge on transmission and prevention of HIV and irrational fear of HIV transmission were significant related with stigmatized attitudes $(\mathrm{p}<0.05)$. Type of HCW, marital status, age, knowledge on transmission and prevention of HIV and irrational fear of HIV transmission indicated significant $(\mathrm{p}<0.05)$ differences in the levels of discriminatory attitudes. A multiple linear regression model identified type of HCW and irrational fear of HIV transmission correlated with stigmatized attitudes $\left(\mathrm{R}^{2}=0.230\right)$ and knowledge on transmission and prevention of HIV correlated with discriminatory attitudes $\left(\mathrm{R}^{2}=0.119\right)$.

Conclusion: Irrational fear of HIV transmission and type of HCW are significant predictors to stigmatized attitudes; knowledge on transmission and prevention of HIV is a predictor to discriminatory attitudes towards PLHIV among HCWs. (Med J Indones. 2013;22:22-9)
\end{abstract}

Keywords: Discrimination, discriminatory attitudes, HIV, PLHIV, stigmatized attitudes.

Stigma has been described as a dynamic process of devaluation that 'significantly discredits' an individual in the eyes of others thus reducing that individuals status in the eye of society. ${ }^{1}$ Stigma can stem from a particular characteristic. ${ }^{2}$ HIV-related stigma tending to build upon and reinforce negative connotations through the association of HIV and AIDS with already-marginalized behaviors, such as sex worker, drug use, and homosexual and transgender sexual practice. ${ }^{2}$ Discrimination is an aspect of stigma defined as a form of exclusion, or restriction of expression, marginalization, or prevention from access to something or services. ${ }^{3}$ When stigma is 
acted upon, the result is discrimination. Discrimination consists of actions or omissions that are derived from stigma and directed towards those individuals who are stigmatized. ${ }^{2}$ HIV-related discrimination refers to any form of arbitrary distinction, exclusion, or restriction affecting PLHIV. ${ }^{3}$

HIV-related stigma and discrimination are major barriers to effective and sustainable prevention, care, treatment, and support efforts. ${ }^{4,5}$ It tends to create a hidden epidemic of the disease based on socially-shared ignorance, fear, misinformation, and denial. ${ }^{3,6}$ HIV-related stigma and discrimination can cause people to refute risk, refuse testing, delay treatment, not disclose their HIV status, and not seek public assistance. ${ }^{7}$ Studies found that experience of stigma and discrimination or fear of being stigmatized and discrimination produce anxiety, depression, guilt, isolation, low self-esteem, disruption of family dynamics, physical and emotional violence, intensification of grief, and loss of social support, which in turn influence the PLHIV toward seeking voluntary counseling and testing (VCT), accessing HIV treatment and care, adhering to antiretroviral therapies, accessing education and information on preventive behaviors, and attending programs to prevent mother-to-child transmission, all of which have a great impact on public health. ${ }^{4,8,9}$

Stigmatized and discriminatory attitudes toward PLHIV are not prevailing only among the general public at large, but several studies have indicated that the existence of high levels of stigmatized and discriminatory attitudes among health care workers (HCWs) also. ${ }^{10-15}$ There are many ways in which HIVrelated stigma manifests in health care settings. ${ }^{5,9,16}$ Studies from difference countries found that various factors affecting stigmatized and discriminatory attitudes toward PLHIV among HCWs including level of irrational fear of HIV transmission, type of hospital, level of education, gender, high-risk taking behavior, individuals related to stigmatized identities, sources of HIV infection, stage of the disease, relationship with an infected person, ethnicity and urban-rural locality. ${ }^{11,17}$

Study on HIV-related stigma and discrimination is important from both public health and human rights perspectives. ${ }^{2}$ However; recently, there has been no study of HIV-related stigma and discrimination among HCWs in Aceh. In this context, this study was conducted to explore stigmatized and discriminatory attitudes towards PLHIV among HCWs in Aceh. This study adopted the oretical position that discrimination is an outcome of stigmatization and attempted to measure discrimination using hypothetical questions about readiness of HCWs to interact with or provide health care services to PLHIV as previously described..$^{9,11}$

\section{METHODS}

\section{Study design}

The original study from which the findings presented in this paper were taken was designed to identify the levels and correlates of different aspects of stigmatized and discriminatory attitudes toward PLHIV among HCWs (doctors, nurses, and medical student intern). Non-probability judgment sampling method was used.

\section{Recruitment and procedure}

The study was cross-sectional in nature. Eighty nine HCWs (32 males and 57 females), interviewed for the study, were recruited from Dr. Zainoel Abidin General Hospital, Banda Aceh, Indonesia. All HCWs were asked to participate and there was no incentive was given to the participants. Authors interviewed the HCWs faceto-face. HCWs were selected purposively and therefore no participation rate was calculated. Data were collected on August 2011. Informed consent obtained from all participants. This study approved by the Institutional Review Board (IRB) Faculty of Medicine, Syiah Kuala University, Banda Aceh, Indonesia.

\section{Questionnaire}

A structured questionnaire was used for data collection based on previous study. ${ }^{9,11}$ The questionnaire covered sociodemographic, cultural and religious variables, experience direct contact with PLHIV, knowledge on transmission and prevention of HIV, irrational fear of HIV transmission, and stigmatized and discriminatory attitudes toward PLHIV.

\section{Measures}

\section{Dependent variables}

Stigmatized attitudes were measured by using 15 -items instrument as previously described. ${ }^{9}$ Items were measured on a 5-point Likert-type scale. Higher scores reflected more stigmatized attitudes toward PLHIV. Based on previous study the items were highly internally consistent with each other, and the reliability coefficient was $0.93 .{ }^{9}$ Discriminatory attitudes were measured via 16 items selected covering both social- and health care-related discriminatory attitudes towards PLHIV as previously described. ${ }^{11}$ Items were measured on a 5-point Likerttype scale indicating their agreement or disagreement. The higher score on this scale reflected the higher level of discrimination. Based on previous study the reliability coefficient of this scale was 0.92 , indicating high internal consistency among the items. ${ }^{11}$ 


\section{Independent variables}

a. Knowledge on transmission and prevention of HIV

A 10-item instrument adopted from Hossain and Kippax $^{9,11}$ was used to measure the knowledge on transmission and prevention of HIV among the HCWs. Higher scores indicate greater knowledge on transmission and prevention of HIV. In the previous study the reliability coefficient of these items was $0.71 .^{9,11}$

\section{b. Irrational fear of HIV transmission}

A 12-item instrument adopted from Hossain and $\operatorname{Kippax}^{9,11}$ was used to measure the irrational fear of HIV transmission among the HCWs. Higher scores indicate more irrational fear of HIV transmission. In the previous study the reliability coefficient of these items was $0.91 .^{9,11}$

\section{c. Other measures}

In addition to the above-mentioned independent variables, the following variables were also considered in analyzing the correlates of stigmatized and discriminatory attitudes towards PLHIV: age, sex, education, and religion, importance of religion in the HCW's life, marital status, type of HCW and having direct contact with PLHIV at work.

\section{Statistical analysis}

Data were analyzed at two levels. At the bivariate level, the relationship between the dependent variable and the continuous variables were examined through correlation coefficient. One-way analysis of variance (ANOVA) was used to examine the relationship between the dependent variable and the categorical and ordinal variables. The variables that were significant $(\mathrm{p}<0.05)$ at bivariate analysis were entered into the multiple linear regression model. Multiple linear regression was used to determine the variables that correlated with stigmatized and discriminatory attitudes. Stigmatized and discriminatory attitudes analyzed separately. The assumptions of linear regression, such as linearity, normality, homogeneity of variance, were checked and met.

\section{RESULTS}

\section{Sample characteristics}

Sample characteristics of the participants of this study are presented in Table 1 . Majority (64\%) of the participants was female, and the average age of the respondents was 27 years. The large majority (96.6\%) of the respondents was Islam and $60.7 \%$ participants were single. More than a half (57\%) of the respondents had had direct contact with PLHIV in their workplace.

Table 1. Sample characteristics of health care workers by the occupational position

\begin{tabular}{|c|c|c|c|c|}
\hline \multirow[b]{2}{*}{ Sample characteristics } & \multicolumn{4}{|c|}{ Percentage of health care workers } \\
\hline & $\begin{array}{l}\text { Doctor } \\
(\mathrm{n}=18)\end{array}$ & $\begin{array}{l}\text { Nurse } \\
(\mathrm{n}=24)\end{array}$ & $\begin{array}{l}\text { Medical student intern } \\
\qquad(\mathrm{n}=47)\end{array}$ & $\begin{array}{c}\text { Total } \\
(\mathrm{n}=89)\end{array}$ \\
\hline \multicolumn{5}{|l|}{ Sex } \\
\hline Male & 38.9 & 33.3 & 36.2 & 36 \\
\hline Female & 61.1 & 66.4 & 63.8 & 64 \\
\hline Age (average in years) & 29 & 33 & 23.6 & 27 \\
\hline \multicolumn{5}{|l|}{ Education } \\
\hline Diploma III & 0 & 58.3 & 0 & 15.7 \\
\hline Diploma IV & 100 & 41.7 & 100 & 84.3 \\
\hline \multicolumn{5}{|l|}{ Religion } \\
\hline Islam & 83.3 & 100 & 100 & 96.6 \\
\hline Non Islam & 16.7 & 0 & 0 & 3.4 \\
\hline \multicolumn{5}{|l|}{ Marital status } \\
\hline Single & 44.4 & 16.7 & 89.4 & 60.7 \\
\hline Married & 55.6 & 83.3 & 10.6 & 39.3 \\
\hline \multicolumn{5}{|c|}{ Importance of religion in respondent's life } \\
\hline Important & 16.7 & 12.5 & 8.5 & 11.2 \\
\hline Very important & 83.3 & 87.5 & 91.5 & 88.8 \\
\hline
\end{tabular}


In term of importance of religion in respondent's life, vast majority $(88.8 \%)$ participants stated religion was very important.

\section{Level and correlates of stigmatized and discriminatory attitudes}

The average score of the scale on avoidance attitudes toward PLHIV in hypothetical situations was 35.5, which varied significantly among different occupation groups. The average of stigmatized attitudes among doctors was significantly different from those of nurses and medical student interns, and between nurses and medical student interns (Table 2). Analysis found that three out of 7 categorical and ordinal variables education, marital status and type of HCW - indicated significant differences in the levels of stigmatized attitudes.
The average score of the scale on discriminatory attitudes toward PLHIV was 38.8. The average of stigmatized attitudes among doctors and medical student interns was significantly different from those of nurses (Table 3). In addition, two out of 7 categorical and ordinal variables - marital status and type of HCW - indicated significant differences in the levels of stigmatized attitudes.

Strength of relationship between the dependent variable and the continuous variables was examined through correlation coefficients. The results of the correlation coefficient between the dependent variable and all the continuous were highly statistically significant (Table 4). It was observed that the level of stigmatized attitudes increased with the increment of irrational fear of HIV transmission. Conversely, high knowledge on transmission and prevention of HIV produces less

Table 2. ANOVA of stigmatized attitudes in hypothetical situations among HCWs $(\mathrm{n}=89)$

\begin{tabular}{|c|c|c|c|c|c|}
\hline \multirow{3}{*}{ Variable } & \multicolumn{4}{|c|}{ Stigmatized attitudes } & \multirow{3}{*}{$\mathrm{p}$} \\
\hline & \multirow{2}{*}{$\mathrm{N}$} & \multirow{2}{*}{ Mean } & \multicolumn{2}{|c|}{$95 \% \mathrm{CI}$ for mean } & \\
\hline & & & Lower limit & Upper limit & \\
\hline \multicolumn{6}{|l|}{ Sex } \\
\hline Male & 32 & 38.5 & 34.41 & 42.59 & 0.820 \\
\hline Female & 57 & 39.0 & 37.25 & 40.75 & \\
\hline \multicolumn{6}{|l|}{ Education } \\
\hline Diploma III & 14 & 44.2 & 38.13 & 50.30 & $0.009 *$ \\
\hline Diploma IV & 75 & 37.8 & 36.02 & 39.61 & \\
\hline \multicolumn{6}{|l|}{ Religion } \\
\hline Islam & 86 & 39.1 & 37.25 & 40.91 & 0.123 \\
\hline Non Islam & 3 & 31.3 & 17.65 & 45.01 & \\
\hline \multicolumn{6}{|l|}{ Marital status } \\
\hline Single & 54 & 37.2 & 35.20 & 39.28 & $0.030 *$ \\
\hline Married & 35 & 41.3 & 37.96 & 44.55 & \\
\hline \multicolumn{6}{|l|}{ Type of HCW } \\
\hline Doctor & 18 & 35.4 & 32.79 & 37.99 & $0.001 *$ \\
\hline Nurse & 24 & 44.3 & 40.30 & 48.29 & \\
\hline Medical student intern & 47 & 37.3 & 35.02 & 39.66 & \\
\hline \multicolumn{6}{|c|}{ Had any direct contact with PLHIV at work } \\
\hline Yes & 51 & 38.2 & 35.63 & 40.76 & 0.428 \\
\hline No & 38 & 39.6 & 37.11 & 42.20 & \\
\hline \multicolumn{6}{|c|}{ Importance of religion in respondent's life } \\
\hline Important & 10 & 41.5 & 34.97 & 48.03 & 0.295 \\
\hline Very important & 79 & 38.5 & 36.58 & 40.38 & \\
\hline
\end{tabular}

ANOVA = Analysis of variance; $\mathrm{CI}=$ Confidence interval; $\mathrm{HCW}=$ Health care workers; PLHIV = People living with HIV; $*=$ Statistically significant 
Table 3. ANOVA of discriminatory attitudes among HCWs $(n=89)$

\begin{tabular}{|c|c|c|c|c|c|}
\hline \multirow{3}{*}{ Variable } & \multicolumn{4}{|c|}{ Discriminatory attitudes } & \multirow{3}{*}{$\mathrm{p}$} \\
\hline & \multirow{2}{*}{$\mathrm{N}$} & \multirow{2}{*}{ Mean } & \multicolumn{2}{|c|}{$95 \% \mathrm{CI}$ for mean } & \\
\hline & & & Lower limit & Upper limit & \\
\hline \multicolumn{6}{|l|}{ Sex } \\
\hline Male & 32 & 34.2 & 30.41 & 37.96 & 0.324 \\
\hline Female & 57 & 36.3 & 33.89 & 38.67 & \\
\hline \multicolumn{6}{|l|}{ Education } \\
\hline Diploma III & 14 & 38.0 & 31.46 & 44.54 & 0.295 \\
\hline Diploma IV & 75 & 35.1 & 32.95 & 37.18 & \\
\hline \multicolumn{6}{|l|}{ Religion } \\
\hline Islam & 86 & 35.6 & 33.56 & 37.72 & 0.559 \\
\hline Non Islam & 3 & 32.3 & 28.54 & 36.13 & \\
\hline \multicolumn{6}{|l|}{ Marital status } \\
\hline Single & 54 & 33.6 & 31.48 & 35.71 & $0.028 *$ \\
\hline Married & 35 & 38.5 & 34.63 & 42.40 & \\
\hline \multicolumn{6}{|l|}{ Type of HCW } \\
\hline Doctor & 18 & 33.7 & 30.50 & 36.95 & $0.016^{*}$ \\
\hline Nurse & 24 & 40.3 & 34.60 & 45.90 & \\
\hline Medical student intern & 47 & 33.8 & 31.65 & 35.96 & \\
\hline \multicolumn{6}{|c|}{ Had any direct contact with PLHIV at work } \\
\hline Yes & 51 & 34.9 & 32.12 & 37.76 & 0.505 \\
\hline No & 38 & 36.3 & 33.36 & 39.27 & \\
\hline \multicolumn{6}{|c|}{ Importance of religion in respondent's life } \\
\hline Important & 10 & 36.4 & 30.22 & 42.58 & 0.761 \\
\hline Very important & 79 & 35.4 & 33.24 & 37.59 & \\
\hline
\end{tabular}

$\mathrm{ANOVA}=$ Analysis of variance; $\mathrm{CI}=$ Confidence interval; $\mathrm{HCW}=$ Health care workers; PLHIV = People living with HIV; $*$ = Statistically significant

Table 4. Correlation analysis for stigmatized and discriminatory attitudes of HCWs with ratio scale independent variable

\begin{tabular}{|c|c|c|c|c|c|}
\hline \multirow{2}{*}{ Independent variable } & \multirow[t]{2}{*}{$\mathrm{n}$} & \multicolumn{2}{|c|}{ Stigmatized attitude } & \multicolumn{2}{|c|}{$\begin{array}{c}\text { Discriminatory } \\
\text { attitudes }\end{array}$} \\
\hline & & $\mathrm{R}$ & $\mathrm{p}$ & $\mathrm{R}$ & $\mathrm{p}$ \\
\hline Age & 89 & 0.166 & 0.120 & 0.259 & 0.014 \\
\hline Knowledge on transmission and prevention of HIV & 89 & -0.258 & 0.015 & -0.345 & 0.001 \\
\hline Irrational fear of HIV transmission & 89 & 0.418 & 0.000 & 0.230 & 0.030 \\
\hline
\end{tabular}

$\mathrm{HCW}=$ Health care workers; $\mathrm{R}=$ Person correlation

stigma toward PLHIV. In term of discriminatory attitudes, it was found that the level of discriminatory attitudes increased with the increment of age and irrational fear of HIV transmission and decreased with high knowledge on transmission and prevention of HIV.
The variables that were statistically significant in bivariate analysis were entered into a multiple linear regression model. Stigmatized attitudes and discriminatory attitudes analyzed separately. The multicolinearity was assessed among the relevant variables before entering the variables into the 
regression model. There was no multicolinearity was assessed among independent variables. The full regression model for stigmatized attitudes was highly significant $\left(\mathrm{F}_{(5,83)}=5.933 ; \mathrm{p}<0.001\right)$, with an $\mathrm{R}^{2}$ of 0.263 . In the full model, the variables remained significant after controlling the effect of other variable were type of $\mathrm{HCW}$ and irrational fear of HIV transmission. A reduced regression model, where only the significant variables of the full model were entered, was also significant after controlling the effect of other variables $\left(\mathrm{F}_{(2,86)}=12.819 ; \mathrm{p}<0.001\right)$, with an $\mathrm{R}^{2}$ of 0.230 . The result shows that the level of stigmatized attitudes will increase with the increment of irrational fear of HIV transmission. In terms of type of $\mathrm{HCW}$, nurses had more stigmatized attitudes when compared with doctors.

In term of discriminatory attitudes, the full regression model for discriminatory attitudes was highly significant $\left(\mathrm{F}_{(5,83)}=4.155 ; \mathrm{p}<0.05\right)$, with an $\mathrm{R}^{2}$ of 0.200 . In the full model, the variable remained significant after controlling the effect of other variable was knowledge on transmission and prevention of HIV. A reduced regression model for discriminatory attitudes was also significant $\left(\mathrm{F}_{(1,87)}=11.791 ; \mathrm{p}<0.05\right)$, with an $\mathrm{R}^{2}$ of 0.119 . The result shows that the level of discriminatory attitudes will reduce with the increment of knowledge on transmission and prevention of HIV.

\section{DISCUSSION}

Stigmatized and discriminatory attitudes among HCWs were common in this study and this finding is similar to the findings conducted outside Indonesia. Some studies found that sex of HCWs was not significant influenced neither stigmatized or discriminatory attitudes towards PLHIV among HCWs. ${ }^{7,9}$ However, study in Belize and China found that female HCWs were more stigmatizing in their attitudes of blame/ judgment than male. ${ }^{18,19}$ Andrewin and Chien ${ }^{18}$ stated that the possible reasons for this condition was women to be more homophobic than men and women also suffer much greater social consequences for behavior that is deemed to be sexually or morally deviant by society. Conversely, some studies found that female HCWs evoked less discriminatory attitudes. $^{12,20}$

This study, similar with previous study, ${ }^{7}$ found that age was not influenced stigmatized attitudes, whereas age was positively related to discriminatory attitudes among HCWs. Some researchers found that age was a positive predictor of stigmatized and discriminatory attitudes.9,11,18 Possible reasons for the higher stigmatized and discriminatory attitudes toward PLHIV among older HCWs in this study are that many HCWs are aged and because of this, may not have received a curriculum with standardized HIV/AIDS information and may not have attended intensive HIV in-service programs and there were less likely to have attended continuing education training courses on HIV/AIDS. Some studies found that younger practitioners were less stigmatizing than older practitioners. ${ }^{13,19}$ However, age was not consistently as positive predictor of stigmatized and discriminatory attitudes toward PLHIV among HCWs. In some studies age was found to be a negative predictor for stigmatized and discriminatory attitudes. $^{18,21}$

In this study married HCWs showed higher stigmatized and discriminatory attitudes among HCWs. There was not available theory to explain this condition. We believe that married HCWs more attention to their family (their children), thus produces higher stigmatized and discriminatory attitudes. In term of HCWs education, this study showed education influenced stigmatized attitudes but did not influence discriminatory attitudes. More education produced less stigma toward PLHIV. Study in Bangladesh also found same result. ${ }^{9}$ In addition study in Bangladesh showed year of education evoked less discriminatory attitudes. ${ }^{11}$ The possible reason for this condition was more educated HCWs received more curriculums with standardized HIV/AIDS information.

According to general literature, HCWs who are more religious tend to be more stigmatizing toward PLHIV believed to have contracted the virus through morally sanctioned practices. ${ }^{22}$ However, in this study neither religion nor importance of religion in HCWs life associated with stigmatized and discriminatory attitudes. The possible reason for this situation was 96.6\% of respondent are Muslim and it was making the homogeneity of respondent in this study. Andrewin and Chien ${ }^{18}$ study found that HCWs who described themselves as being religious were more stigmatizing in attitudes of blame/judgment but not associated with discriminatory attitudes. Interestingly, a study observed that religion was influence discriminatory attitudes and the level of discriminatory attitudes increased with importance of religion in HCWs life. ${ }^{15}$

Prior exposure to PLHIV usually decreases stigmatized and discriminatory attitudes by HCWs certain kinds of exposure highlight status differentials between patients and HCWs rather than creating more empathy. ${ }^{23}$ Professional contact with PLHIV is likely to have reduced discriminatory attitudes as has been shown in some studies. ${ }^{24,25}$ However, this study direct contact with PLHIV was not associated with stigmatized and discriminatory attitudes toward PLHIV among HCWs. 
In this study, doctors showed lowest stigmatized and discriminatory attitudes, followed by medical student interns and nurses. The possible reason for this condition was doctors have higher knowledge on transmission and prevention of HIV followed by medical student interns. This is supported by the results of a previous study where high levels of knowledge on transmission and prevention of HIV were found among higher occupational categories. ${ }^{26}$ However, some studies showed converse result. Li et al ${ }^{12}$ found that higher-status medical professional with more medical education and those occupying positions at higher level medical facilities showed more prejudicial attitudes towards PLHIV and less willingness to have social interaction with PLHIV patients. This may be due to increased status differentials between HCWs and patients, as Sadow et $\mathrm{al}^{27}$ suggested, but in hospital settings it may also be due to the increased capacity to exploit status differentials between HCWs compared with junior doctors, for example, senior doctors have more power to delegate what they see as high-risk tasks with PLHIV patients. ${ }^{23}$ However, some studies failed to show the influence type of HCW to stigmatized and discriminatory attitudes. ${ }^{7,15}$

Knowledge on transmission and prevention of HIV was found to be one of the positively predictors of stigmatized and discriminatory attitudes toward PLHIV. On the other hand, more education and high knowledge on transmission and prevention of HIV produces less stigmatized and discriminatory attitudes toward PLHIV and had a more positive feeling and view about care of PLHIV patients. ${ }^{9,11}$ However, the other study found that knowledge on transmission and prevention of HIV did not change behaviors. ${ }^{21}$ Although the physicians know well about the routes of transmission, they do not believe it by heart. Therefore, their fear of being infected makes them discriminate against the PLHIV.$^{14}$ Virtually research has long attempted to establish the relationship between knowledge on transmission and prevention of HIV, fear of infection and stigma or discrimination toward PLHIV. Some studies find a close relationship and others do not. $\mathrm{Li}$ et $\mathrm{al}^{12}$ found that it was fear of infection rather than knowledge on transmission and prevention of HIV which was related to health professionals' willingness to interact with PLHIV.

Irrational fear of HIV transmission found to be one of predictor of stigmatized and discriminatory attitudes toward PLHIV. This study supports previous study. ${ }^{9,11,12}$ Causes of irrational fear of HIV transmission is complex. Previous study found irrational fear of HIV transmission is associated with the positioning of PLHIV as "other," already stigmatized groups in the society such as homosexuals, sex workers, injecting drug users..$^{28}$ Thus, the fear about transmission of HIV is mostly psychological, based on prejudice and irrational beliefs. ${ }^{9}$ Deacon \& Boulle ${ }^{23}$ stated that fear of infection in HCWs may be more likely to be related to the latter more specific forms of knowledge, to likely exposure, and to the capacity to manage the risk of infection (e.g. availability of gloves when necessary) than to general knowledge about transmission modes. However, the rational fear of exposure to HIV among HCWs is important to prevent transmission of HIV to HCWs.

The findings of this study have serious implications for public-health policy planners and human rights activists. High levels of stigmatized and discriminatory attitudes among the HCWs influence the decisionmaking process of the PLHIV and stop them from accessing VCT, care, support, and treatment services. Additionally, experience of discrimination increases the depression and reduces the level of self-esteem among the PLHIV, which is adversely related to a number of issues, i.e. high-risk behavior for transmitting HIV to others, low self-efficacy, and low adherence to antiretroviral therapy. To have a full understanding of stigmatized and discriminatory attitudes of HCWs, they should be studied in the context of the broader socioeconomic milieu in which they live and work. First, class structure and power relations between the HCWs and the PLHIV should be considered. Second, the attitudes of HCWs are influenced by the society's existing perceptions towards PLHIV; for example, people will not visit those $\mathrm{HCWs}$ who provide treatment to PLHIV. Discriminatory attitudes among the general public constrain HCWs from treating PLHIV. Third, safety in the workplace is a concern for HCWs. The HCWs became more fearful in the absence of universal precaution in the health care system, and this also evokes discrimination towards PLHIV.

This study is not, however, without limitations. First, self-reported stigmatized and discriminatory attitudes, instead of actual stigmatized and discriminatory behavior, were studied. These attitudes were measured by some specific hypothetical questions, and hypothetical questions may suffer from bias due to the possibility of respondents providing responses that are socially acceptable rather than being correct which can be termed social desirability bias. The present study suggests that in terms of scope, a wider audience can be educated through well structured health talks and seminars which would include in-service training and continuing medical education specially designed for the particular target group.

This research found that being doctor and less irrational fear of HIV transmission evoked less stigmatized 
attitudes towards PLHIV among HCWs. High knowledge on transmission and prevention of HIV is the only one positive predictor to discriminatory attitudes towards PLHIV among HCWs.

\section{Acknowledgments}

The authors would like to express their appreciation to Tilaili Ibrahim, MD, Nurjannah, MD, Makmur Mohd. Zein, MD and Rachmad Suhanda, MD from Department of Public Health, Faculty of Medicine, Syiah Kuala University, Banda Aceh, Indonesia.

\section{REFERENCES}

1. Monjok E, Smesny A, Essien EJ. HIV/AIDS - related stigma and discrimination in Nigeria: review of research studies and future directions for prevention strategies. Afr J Reprod Health. 2009;13:21-35.

2. Aggleton P, Wood K, Malcolm A, et al. HIV-related stigma, discrimination and human rights violations: case studies of successful programmes. Geneva, Switzerland: UNAIDS; 2005.

3. UNAIDS. HIV and AIDS-related stigmatization, discrimination and denial: forms, contexts and determinants. Research studies from Uganda and India [Internet]. Geneva, Switzerland; 2000 [cited 20 Agt 2012]. Available from: http://data.unaids.org/Publications/IRCpub01/jc316-uganda-india_en.pdf.

4. Parker R, Aggleton P, Attawell K, et al. HIV/AIDS-related stigma and discrimination: a conceptual framework and an agenda for action. Horizon Program. New York: Population Council; 2002.

5. Health Policy Initiative, Task Order 1. Measuring the degree of HIV-related stigma and discrimination in health facilities and providers: working report. Washington, DC: Futures; 2010.

6. Parker R, Bajenja E, Karamagi E, et al. AIDS-felated stigma: perceptions of family care givers and health volunteers in Western Uganda. World Health and Population Report; 2007.

7. Oe A. HIV related stigmatizing attitude and practice among health care workers in Northern Nigeria. J Infect Dis Immun. 2011;3:226-32.

8. UNAIDS. HIV-related stigma and discrimination: a summary of recent literature [Internet]. 2009 [cited 20 Agt 2012]. Available from: http://data.unaids.org/pub/ Report/2009/20091130_stigmasummary en.pdf.

9. Hossain MB, Kippax S. Stigmatized attitudes toward people living with HIV in Bangladesh: health care workers' perspectives. Asia Pac J Public Health. 2011;3:171-82.

10. Bharat S, Aggleton P, Tyrer P. India. HIV and AIDS-related discrimination, stigmatization and denial. Geneva: Joint United Nations Programme on HIV/AIDS; 2001. p. 16-7.
11. Hossain MB, Kippax S. HIV-related discriminatory attitudes of healthcare workers in Bangladesh. J Health Popul Nutr. 2010;28:199-207.

12. Li L, Zunyou W, Sheng W, et al. HIV-related stigma in health care settings: a survey of service providers in China. AIDS Patient Care STDs. 2007;21:753-62.

13. Mahendra VS, Gilborn L, George B, et al. Reducing AIDSrelated stigma and siscrimination in Indian hospitals. Horizons Program, Tulane University; May 2006.

14. UllahAKMA.HIV/AIDS-related stigma and discrimination: a study of health care providers in Bangladesh. J Inter Assoc Physic AIDS Care. 2011;2:97-104.

15. Reis C, Heisler M, Amowitz LL, et al. Discriminatory attitudes and practices by health workers toward patients with HIV/AIDS in Nigeria. PLoS Med. 2005;2:e246.

16. Banteyerga H, Kidanu A, Nyblade L, et al. Exploring HIV and AIDS stigma and related discrimination in Ethiopia: causes, manifestations, consequences, and coping mechanisms. Addis Ababa: Miz-Hasab Research Center; 2004.

17. Wong LP, Syuhada ARN. Stigmatization and discrimination towards people living with or affected by HIV/AIDS by the general public in Malaysia. Southeast Asian J Trop Med Public Health. 2011;42:1119-29.

18. Andrewin A, Chien LY. Stigmatization of patients with HIV/AIDS among doctors and nurses in Belize. AIDS Patient Care and STDs. 2008;22:897-906.

19. Solomon P, Guenter D, Stinson D. People living with HIV as educators of health professionals. AIDS Patient Care STDs. 2005;19:840-7.

20. Mulaudzi MV, Pengpid S, Peltzer K. Nurses' knowledge, attitudes, and coping related to HIV and AIDS in a rural hospital in South Africa. Ethno Med. 2011;5:25-32.

21. Ulasi CI, Preko PO, Baidoo JA, et al. HIV/AIDS-related stigma in Kumasi, Ghana. Health Place. 2009;15:255-62.

22. Kopacz DR, Grossman LS, Klamen DL. Medical students and AIDS: knowledge, attitudes and implications for education. Health Educ Res. 1999;14:1-6.

23. Deacon H, Boulle A. Commentary: factors affecting HIV/AIDS-related stigma and discrimination by medical professionals. Int J Epidemiol. 2006;36:185-6.

24. Kalichman SC, Simbayi LC, Jooste S, et al. Development of a brief scale to measure AIDS-related stigma in South Africa. AIDS Behav. 2005;9:135-43.

25. Kalichman SC, Simbayi LC. Traditional beliefs about the cause of AIDS and AIDS-related stigma in South Africa. AIDS Care. 2004;16:572-80.

26. Walusimbi M, Okonsky JG. Knowledge and attitude of nurses caring for patients with HIV/AIDS nursing in Uganda. J Appl Nurs Res. 2004;17:92-3.

27. Sadow D, Ryder M, Webster D. Is education of health professionals encouraging stigma towards the mentally ill? J Ment Health. 2002;11:657-65.

28. Aggleton P. HIV and AIDS-related discrimination, stigmatization and denial. Comparative analysis: research studies from India and Uganda. Geneva, Switzerland: UNAIDS; 2000. 